\title{
Trust building or vested interest? Social capital processes of cross-border cooperation in the border towns of Tornio and Haparanda
}

\begin{abstract}
During the recent decade, scholars have started to pay more attention to how the local socioinstitutional environment affects the outcome of regional cross-border cooperation (CBC) programs and projects. This paper studies the social capital processes of $\mathrm{CBC}$, particular focus being on how power and trust relations are manifested in project networking and implementation governed by public authorities. The examination focuses on the border towns of Tornio (Finland) and Haparanda (Sweden) which share a common cultural history and a long tradition of cooperation. The results, based on document analysis and 16 interviews, show that the $\mathrm{CBC}$ at Tornio-Haparanda is not unproblematic but contested by different interest groups and actors. It involves practices of inclusion and exclusion that influence mobilization, engagement and trust building between different actors. The social capital processes are intertwined with the local norms and values as well as with the strategic networking and pursuance of specific development objectives.
\end{abstract}




\section{Introduction}

The number of cross-border cooperation (CBC) initiatives in Europe, and political and scholarly interest in them, has increased remarkably in the past 30 years (Clément \& Lamour 2011; Prokkola et al. 2015; Jacobs \& Kooij 2013; Ferrer-Gallardo 2009). Of particular interest are the CBC initiatives associated with the EU-co-funded Interreg program, which is one of the key instruments for the implementation of the territorial cohesion policy of the EU. Both failures and success stories of Interreg cooperation have been reported (Jacobs \& Kooij 2013; Medeiros 2014). The failures of cross-border initiatives are typically explained by pointing out that the program regions are established as top-down technocratic entities (Perkmann 2002) and by citing an overoptimistic belief in European collaboration. Differences and hindrances created by state borders cannot easily be erased on the local level, however. (Jacobs \& Kooij 2013).

CBC is often approached in terms of a network, governance, coordination, integration, etc. (Gonzales-Gomez 2014, p. 136-137). Yet, in attempts to understand the reported limited returns of such development strategies, which Interreg-programs exemplify par excellence, growing attention is being paid to the role of institutions and social capital (Rodriguez-Pose 2013, p. 1036; Mirwaldt 2012; Amin 2001; Trippl 2008). Trust and social capital are associated with stronger economic performance; they are understood to lower transaction costs and encourage knowledge-transfer, cooperation and innovation (Knack \& Keefer 1997; Malecki 2012). Especially in peripheral regions where economic prospects are considered to be limited, the strengthening of social capital is seen as an important instrument in the activation of the endogenous development potential of local communities (Pilecek et al. 2013).

This paper will study the processes of social capital in the border towns of Tornio and Haparanda, located on the Finnish-Swedish border, with a particular focus on the formation of trust and power relationships in the context of Interreg A cooperation. As it is governed mainly with public funds, Interreg operates in an institutional setting which is dominated by public authorities and their interests. This fact notwithstanding, the question of power and trust-relations between different interest groups has not been discussed or examined in depth in the previous studies of CBC and social capital (Grix \& Knowles 2003; Häkli 2009; Clement \& Lamour 2011; Mirwaldt 2012; Jakola 2013; Gonzalez-Gomez 2014; Svensson 2015). In order to understand the processes of social capital in $\mathrm{CBC}$ initiatives, which involve various stakeholders and interest groups from two or more 
countries, the question of power is of crucial importance. Starting from a conception that the exercise of power is a question of constraining or dominating others (see Allen 1997), this paper approaches power not so much as a resource which inheres in certain social relationships but more as an ability to mobilize resources (money, time, knowledge, existing contacts, etc.) and use them to secure specific interests and outcomes (Allen 1997, p. 62). Of particular interest is how power is mobilized in $\mathrm{CBC}$ networks by actors that have different status positions and resources. The research questions are defined in the following manner:

(1) How is social capital manifested in regional development in the context of CBC in the towns of Tornio and Haparanda?

(2) In what ways are power relations manifested in social capital processes of regional cross-border development?

Before moving on to the empirical examination of the cooperation between Tornio and Haparanda, the paper will first develop a conceptual framework for studying the processes of social capital in CBC. Contrary to studies in which social capital is approached as an unambiguous socio-cultural factor of regional economic growth which can be charted with the help of statistics using indicators such as trust, social networks, civic norms and values (see Pilecek et al. 2013), this paper embraces the argument that there is a need in regional studies to develop a more nuanced understanding of social capital as a complex and constantly evolving process (Malecki 2012). Border regions and $\mathrm{CBC}$ provide an interesting research setting from this perspective not least because of their diversity and peripheral location.

\section{Trust, power and the processes of social capital}

There is no single definition for social capital; it is a highly contested concept. Nevertheless, scholars agree that social capital is connected to social networks. Most conceptualizations start from the writings of key social capital theorists such as Bourdieu, Coleman and Putnam, who eventually brought the concept into the realm of academic and policy discussions of regional development (Malecki 2012, p. 1024). One of the key arguments of Putnam in particular is that social contacts and the norms of reciprocity and trustworthiness affect productivity and economic performance: "when trust and social networks flourish, individuals, firms, neighborhoods and even nations prosper" (Putnam 2000, p. 319). 
Putnam (1993) sees social capital as a public good and as a communality which furthers economic performance, and he discerns social networks, trust and norms as different components of social capital. According to Putnam (2000), it is possible to analytically distinguish both inclusive and exclusive forms of social capital, or what can be called bridging and bonding social capital (see also Gittell \& Vidal 1998). Bridging social capital is associated with weaker ties and is understood to foster better information and knowledge sharing with distant acquaintances in particular. Bridging ties are also seen to be of particular importance in diverse societies, of which border towns and regions provide a fitting example. Bridging ties are understood to expand social identities, open up insular communities of interest, help mitigate intergroup conflicts, and reduce possible hierarchies among groups over time (De Souza Briggs 2004, p. 154).

Recently, Putnam's theory of social capital has been criticized by geographers for treating space as static, pre-existing, and 'given', as well as for neglecting the question of power and agency (Holt 2008, p. 230; Naughton 2014; Mohan \& Mohan 2002). The studies on social capital have been criticized for favoring positive outcomes, and thus for paying little or no attention to the power and conflicts which arise when individuals and groups experience incompatibility between different rationales. Also, in policy circles social capital is usually approached as a resource that can be built "from nothing". In response to this a recent line of criticism has underlined that social capital is not 'a thing' but rather should be approached as a continuous process in which individuals and groups become connected to each other (Malecki 2012, p. 1024) and in which power is exercised (Naughton 2013).

When studying regional cross-border development, it is also helpful to notice that something (trust, networks, or knowledge) becomes social capital only in certain circumstances and institutional contexts (Tura \& Harmaakorpi 2005, p. 115). Following Coleman's functional approach, Tura and Harmaakorpi (2005, p. 1117) argue that social capital should be studied from a resource-based approach in which social capital is connected to action and the actor's capacity to mobilize other actors. Within development institutions like Interreg, agency is manifested in socio-spatial processes, which may then reinforce some forms of social capital while possibly reducing others. Social capital can be understood to emerge from social relations and power relations in diverse ways, continuously evolving as the actors exercise power in and through network relationships (Naughton 2013). Networks are often beneficial for those within the network but the wider effects of social capital and its exploitation are by no means always positive (Putnam 2000, p. 21): 
powerful elites, for example, may exploit social capital to achieve ends which are beneficial only for special interest groups. From the perspective of $\mathrm{CBC}$ the question of power is significant as it creates a particular setting in which different groups with a certain kind of social capital cooperate with other groups across and within state boundaries while excluding others.

From the perspective of networks and power relations, Bourdieu's theory of social capital provides a helpful starting point. For Bourdieu (1986, p. 248-249) social capital, "the aggregate of the actual or potential resources which are linked to possession of a durable network of more or less institutionalized relationships of mutual acquaintance and recognition," is linked with membership in a group. Bourdieu connects social capital to power and understands pursuing social capital as a social struggle as opposed to a positive communal issue (Holt 2012; Riipinen 2008, p. 59-60). The distribution of social capital greatly affects the process and the outcome of community planning and regional development (De Souza Briggs 2004; Malecki 2012, p. 1031). It is therefore important to pay attention to both the possible benefits of social capital and the unequal power relationships of the actors in the network. The existence of insider-outsider problems and vested interests among the members of the network, which also reflect the imbalanced power relations between different interest groups, not only indicates the negative effects of inter-regional cooperation but may also compromise economic performance in the long term.

Alongside social networks, trust is considered a key component of social capital and of crucial importance from the perspective of CBC (Häkli 2009). Misztal (1996, p. 9-10) defines trust as a social mechanism which can be explained by people's beliefs and motivations. To trust is to believe that the results of a person's intended action will be appropriate in our point of view. Trust is the perquisite of effective and productive cooperation as it is seen to "lubricate the inevitable frictions of social life" (Putnam 2000, p. 135), or as Murphy (2006, p. 428) puts it, trust embeds and stabilizes relationships within networks. Häkli (2009) remarks that trust is typically seen as a key factor that influences the willingness of actors to engage in institutional or voluntary activities.

In the literature on regional development, trust is often viewed as a phenomenon distinct from power and as indicative of a neutral or balanced outcome of social negotiations, thus ignoring the inevitable power differentials that agents mobilize as means for achieving coordination or control of the behavior of others (Murphy 2006, p. 435). Also, regional CBC and engagement will not automatically lead to trust, since the nature of the engagement and the power relations among actors partly determine whether it will result in increased trust (Rohe 2004, p. 163). It is assumed that trust 
building and social capital can be effectively facilitated in cross-border communities, which tend to have a common history, common 'rules' or other mutually shared experiences that the actors can utilize in new trust-building processes (Smallbone et al. 2004, p. 98-99), as is the case in the towns of Tornio and Haparanda. In this paper, the social capital processes of regional cooperation are analyzed through the themes of networks of cooperation, conceptions of trust, institutions and norms. The networks and relationships of cooperation initiatives, through which processes of social capital run, are examined and contextualized in the particular socio-institutional environment of the two border towns, demarcated by the national border and its particular material and cultural dimensions, as well as in the multi-level governance framework of EU CBC.

\section{Research area and methods}

The particular focus in this study are the cross-border initiatives implemented in the border towns of Tornio (22 300 inhabitants) and Haparanda (10 000 inhabitants) located on the Gulf of Bothnia in Finland and Sweden. Their history dates back to the beginning of the $19^{\text {th }}$ century when Finland was annexed to Russia and the border was drawn between the Russian Empire and the Kingdom of Sweden at the Tornio and Muonio Rivers. Tornio and Haparanda are physically close to each other and are not divided by the river like other border villages/towns on the Finnish-Swedish border (see Figure 1). This is because Tornio was originally located on the western side of the Tornio River on an island called Suensaari, but the peace treaty of Hamina in 1809 nevertheless diverted the border to include the trade town in the Russian Empire. The town of Haparanda, previously a village of Tornio, was granted a municipal charter to replace the lost town of Tornio. The new border disrupted the harmony of the river valley which had been a cohesive cultural, economic and political unit in which families lived on both side of the river since the $11^{\text {th }}$ century (Elenius 2008).

Until World War I interaction across the border was relatively free. Due to the strengthening of nationalistic ideologies, Finland gaining independence during the Russian Revolution in 1917, and the 'hardening' of state borders throughout Europe after World War I, the border control became stricter as part of an endeavor to stabilize and harmonize the state territories (Paasi 1996), resulting in general mistrust. Nevertheless, in order to sustain the traditional culture of operating across the river, local municipal development organizations handled border-related development issues such as the problems of border control and need for border infrastructure as matters of great importance and petitioned these issues to the central governments in the national setting (Jakola 2016). In 
Sweden this local mobilization started in the 1940s, almost two decades later than in Finland (Matsson Barsk 1993).

The idea of horizontal interaction across the border developed in increments. The long peaceful relations between the Nordic countries and establishment of Nordic cooperation institutions in the late 1950s are seen to have furthered regional mobilization and CBC (Prokkola 2011). Official bilateral cooperation between Tornio and Haparanda started in the 1960s when the towns agreed about the common use of a swimming hall located in Haparanda. Since then the towns have made several common agreements dealing with, for instance, education, fire and rescue services and a wastewater treatment plant. In 1987 Tornio and Haparanda established a common CBC organization called Provincia Bothniensis whose main aim was to gain economic savings for the towns by intensifying and extending cooperation (Nousiainen 2010, p. 434-436).

Since EU membership for Finland and Sweden in 1995 the region's border location has become a key strategy of regional development and many $\mathrm{CBC}$ projects have gained co-funding from EU structural regional development funds (Jakola 2013; Prokkola et al. 2015). The most extensive and on-going project is called "On the border" in which Tornio and Haparanda are building a common city center in order to further the development of the retail sectors. This Interreg co-funded project has been implemented in different phases already since 1996. Accordingly, economic resources and EU policy rhetoric emphasizing integration have furthered the institutionalization of the cooperation and given it legitimacy (Jakola 2016). Despite the intense cooperation between the towns, studies have shown that a national divide still exists between Finns and Swedes (Lunden \& Zalamanns 2000), particularly as a result of nationalistic integration after the World Wars. The cultural diversity and tradition of long-term institutionalization of CBC makes Tornio and Haparanda an interesting context for studying processes of social capital.

In this study, the social capital processes are studied by applying different methods and materials. First, local project documents and strategies provide material for understanding the background of the initiatives and the institutional context. Second, altogether 16 qualitative interviews were conducted in two phases, in 2012 and 2014, among the stakeholders of the initiatives, including city planners, managers and entrepreneurs in the border towns of Tornio and Haparanda. The selection of the interviewed entrepreneurs was based on their participation in an Interreg co-funded project called "Development of experience industry in the region of Haparanda-Tornio" (or the "Destination" project). The main object of the project was to increase the attractiveness and 
competitiveness of Tornio and Haparanda as a tourism attraction. The project was implemented in 2009-2012 and it received funding from the Interreg IVA North program as well as from the Municipality of Haparanda and the City of Tornio. The Municipality of Haparanda was the leading partner while other partners were the City of Tornio/Team Botnia (a business development organization co-owned by the City of Tornio and local firms) and entrepreneur associations from both Tornio and Haparanda. The project can be seen as a continuum of other Interreg projects that have been implemented in Tornio-Haparanda and the border region.

Altogether eight tourism entrepreneurs and eight public sector stakeholders were interviewed. Four of the interviewees were jointly employed by both Tornio (Finland) and Haparanda (Sweden) or by other binational organizations; eight were employed by Tornio and four by Haparanda. The interviews generally took place in the firms or workplace, but two of the interviews were conducted via phone and one entrepreneur answered by email. The interview questions concerned the dynamics of the CBC projects: how project networks are being built and coordinated, how the communication between different actors is working, and what kind of social relationships are being built. The total length of the recorded interviews (by permission) was approximately one hour each. Many of the interviewed actors had participated in several projects. As social capital is understood as a process, it is fruitful to interview actors who have long-term experiences of CBC and different projects. The analysis here focuses on the narratives of inclusion and exclusion from the networks of cooperation, the articulation of trust and norms of cooperation, the access to resources as well as possible conflicts between different groups.

\section{Social capital processes in the border towns of Tornio and Haparanda}

\section{Building up and coordinating cooperation networks}

The border towns of Tornio and Haparanda have managed several projects since EU membership in 1995, when the opportunity to receive Interreg funding from the Interreg North program was opened. Although the Tornio-Haparanda "Twin city" project provides an example of an EUsupported initiative whose planning started in the favorable atmosphere for cross-border development of the early 1990s (see Jacobs \& Kooij 2013), the towns had well-established networks and cooperation stemming already from the 1960s. From the perspective of current CBC however, the Interreg project as a mode of institutionalized cooperation provides a framework for understanding the formal network-building in projects, as well as the resources that are available. 
The Interreg initiative is premised on a multi-scalar mode of governance framework (EU, nation, region), which means that local and regional authorities, as well as private organizations, create diverse partnerships across and within national boundaries. Local project implementation is steered by the respective national and regional authorities, who, for their part, are accountable to the European Commission. The elements of social capital are visible in the priorities and themes of Interreg program, which represent the keys for the formation and selection of the financed projects. The promotion of social networks and solidarity has been an important part of the regional development strategy of the Interreg IVA North program, whose primary objective is to strengthen regional competitiveness and solidarity. Regional solidarity is understood to entail "a number of social networks and contacts created through face-to-face meetings during the implementation of the programme" (Interreg IVA North 2007, p. 30). The goal of improving the operational environment of local firms by strengthening local commitment, interaction, and networks was also scripted into the strategies of the Destination project in 2010:

The object is to continue the strengthening of local commitment, developing the interaction and building a strong network among project participants. [...] The aims also include creation of a common strategy for Tornio-Haparanda which enables long-lasting co-operation.

Generally, the inclusion of private enterprises reflects the effort to improve the economic effectiveness of Interreg programs. Investing in SMEs, by means of policy objects and budgeting, has increased gradually since the establishment of the first Interreg program in 1991 (Van Den Broek et al. 2015). Nevertheless, it is problematic to commit SMEs with limited time and economic resources (see also O'Dowd 2002) to such cooperation schemes because they are not allowed to gain direct financial benefits from the projects. Interreg guidelines underline that the project funding should not disturb market competition or favor single enterprises but needs to benefit the wider community (see Interreg VA Nord 2016). In the framework of Interreg North programs there have been only a few projects where a private organization has been a leading applicant in a CBC project (Auniola 2017).

Although Tornio and Haparanda are often argued to be models of cooperation (Häkli 2009) and even though their projects have been implemented successfully, there are many conflicting interests which are not documented in the final project reports. In the report of the Destination initiative the overall results were presented relatively optimistically, stating that the cooperation between retail, 
service and tourism entrepreneurs had improved and that the entrepreneurs had gained many opportunities to increase their contact networks within and across the border (Norbotten Länsstyrelsen 2012, p. 5). However, in the interviews a majority of the entrepreneurs described the overall outcomes of the project much more negatively, arguing that the project was relatively unsuccessful. Most of the interviewed entrepreneurs stated that they did not gain any new business partners through the project.

As they are the primary applicants of $\mathrm{CBC}$ projects, public organizations are primarily responsible for the coordination of the projects and, for instance, handle the recruiting and creation of the steering groups. In the policy documents, and also in a number of studies investigating social capital, the building of project networks and mobilization of project partners is often presented as an unproblematic and inclusive process (see for instance Mirwaldt 2013). However, individuals are known to form connections that are beneficial to their own interest (Putnam 2000, p. 19), and the selectivity of connections and networking can be seen in the light of the strategic use of social capital among the members of an interest group. It is therefore important to pay attention to the existing, evolving power relations which manifest themselves in inclusions and exclusions from networks and information chains (Hadjimichalis \& Hudson 2006, p. 860). The interviews in Tornio and Haparanda pointed out that many of the participants had experiences of inclusions and exclusions from the networks, which can be read as manifestations of power and strategic interests. The main problems raised by the entrepreneurs were linked especially to coordination of the project and the unbalanced power positions between different actors, which are, of course, partly a result of the institutional framework and preconditions in which $\mathrm{CBC}$ operates.

In the case of the Destination project, many tourism entrepreneurs saw that the appointing of the steering group was not inclusive, something that was considered problematic because the steering group holds the actual decision-making power over the Interreg project's funding. Of the 35 enterprises participating in the project, 11 represented the tourism industry. Yet the interviews suggest that the voice of SME tourism entrepreneurs was somewhat neglected in the selection of the steering group. This resulted in mistrust towards the city officials:

None of the (small) tourism entrepreneurs were included in the steering group, although it is a tourism project. (TORNIO/PRIVATE/5/MALE) 
Many of the interviewed participants also noted the unbalanced national composition of the steering group. Although the members of the group changed during the project, the last project strategy report, from 2012, indicated that of the seven members of the steering group only one was Finnish. Some of the entrepreneurs in Tornio were disappointed and claimed that the project ended up being more focused on Haparanda and the Swedish side:

1/2: ... they are from Haparanda, they just act in their own interest.

1/1: ...I don't know if there have been active attempts to find anybody for the steering group from the Tornio side or who is responsible for the selections.

(TORNIO/PRIVATE/1/1/FEMALE, TORNIO/PRIVATE/1/2/MALE)

The quality of communication is regarded as a key factor for successful CBC (Mirwaldt 2013). The question of information exchange is central when evaluating possible inclusions and exclusions from the networks. Effective communication, openness and information exchange help in resolving disputes and aligning perceptions and expectations, and promote the building of trust, that is, the interaction between partners is facilitated when they are receiving all necessary and expected information (Aulakh et al. 1996, p. 1012). In the case of cross-border projects, the access to information is often imbalanced as the project management principally has more information than the other participants. The experiences of the Destination project suggest that the information sharing was not very successful and many of the local firms may have unintentionally been excluded by not being informed of the project at the outset. One entrepreneur from Tornio stated that his discovery of the project was more an accidental coincidence than the result of intentional informing by the project management. The methods of communication were also criticized. Many entrepreneurs were hoping for face-to-face or phone contact with the project manager instead of email communication:

Other entrepreneurs who weren't there (in the info meeting) know nothing about the project. [...] When people read their emails they don't necessarily see anything interesting in them. It would be better that somebody would contact by phone. (TORNIO/PRIVATE/2/MALE)

Sometimes the practices resulting in inclusion/exclusion were linked to structural and infrastructural issues. In the Finnish-Swedish border region, most tourism firms are small businesses employing only a few employees. Several entrepreneurs related that it is often challenging or even impossible 
to attend the project meetings, especially if they are organized during office hours, because they are busy running their business and cannot afford to hire a replacement. The planning of timetables exemplifies conflicts of interest, for instance putting small enterprises at a disadvantage compared to other participants; they are at risk of being excluded from information sharing as well as possibilities to participate in decision making as a result.

One of the biggest problems related to the dynamics of the project that was raised by small tourism entrepreneurs was that the bigger firms in Haparanda have more power to influence the decisions of the project. Some interviewed participants explained that this unbalanced power situation resulted from the fact that two firms were investing more economic resources in the project than the smaller firms:

\section{It happens to be that those big companies, they have much more sway and the small businesses are left behind. (TORNIO/PRIVATE/2/MALE)}

This suggests that the actors who have more economic resources to invest in the project also gain a stronger position in the project network. Although one of the guiding principles of the Interreg program is equality and SMEs are one of the main 'target groups', in the actual interaction and networking the representatives of small and large business may have notably different levels of social capital and power. The possibility to mobilize economic resources and thereby pursue one's interests varies between actors in CBC.

\section{Trust and vested interest determine the network dynamics}

It has been shown that rival groups in society may exhibit high levels of social capital within a group but low social capital between them (Mohan \& Mohan 2002, p. 195). The border towns Tornio and Haparanda exemplify an environment in which different levels and forms of social capital exist between different actors and interest groups. The long history of cooperation and mutual learning has resulted in strong personal trust relationships between certain city officials (Jakola 2013), or bonding social capital in Putnam's (1993) terminology. Although it is often argued that bridging social capital is better for regional development as it promotes the diffusion of knowledge, in Tornio and Haparanda thick trust (bonding) relations among the officials have affected regional development positively, for instance by fostering the establishing of an IKEA furniture store in Haparanda in 2006 as part of the "On the border" project (Jakola 2013). It can also 
be argued that from the perspective of CBC, relation-specific trust (Malecki 2012, p. 1029), a trust that is established in cooperative initiatives and tested in action, is of specific importance.

In Tornio and Haparanda $\mathrm{CBC}$ has become a key development object and a means to increase the regional competitiveness of the towns, a strategy to which the city officials are highly committed and which is furthered by the bonding social capital they share. However, like any other bilateral public relationship, $\mathrm{CBC}$ is not unproblematic but also exemplifies the paradox of cooperation and competition (Clarke-Hill et al. 2003) and raises the issue of balancing between common and more vested interests. This is a challenge for both public and private sector actors. In general, CBC is seen to have a positive image that has market value (Hospers 2006). The bilateral cooperation between Tornio and Haparanda has gained positive publicity for being innovative and forward looking in the implementation of the Interreg projects. As a result, actors in Tornio and Haparanda can use this social capital, i.e. the image of expertise in cooperating across the border, as a strategic tool. Although the actual cooperation and trust relations may not always be as unproblematic as represented to the wider audiences, this kind of strategic use of social capital demands trust between stakeholders, even though it is sometimes motivated more by vested than common interests:

We also have difficult issues with Haparanda, but... [...] we keep them to ourselves, which is smart. [...] We always smile with Haparanda and everything is good. (TORNIO/PUBLIC/2/MALE)

Trust relations are always contested and re-articulated in practices (see Bourdieu 1986, p. 250), and therefore represent an important part of the processes of social capital. As Murphy (2006, p. 441) emphasizes, trust-building practices are influenced by actors' perceived power or control of the situation. The interviews with the participants of the Destination project suggest that imbalanced power relations within the project networks set actors in an unequal position and affect trustbuilding processes negatively. Some entrepreneurs underlined the unequal power relations between the entrepreneurs and the city officials. One of the entrepreneurs described that they were like "hostages" in the development projects, without any decision-making power:

Yes, (the entrepreneur) is a hostage there... So they (city officials) can say that entrepreneurs are attending. Entrepreneurs can't really make decisions. I have discussed a lot with the city officials about the issues but they don't listen. 
The ability of groups to engage external authorities, either to influence policies or to bring in useful resources, can be defined as linking social capital (Pretty 2003, p. 1913), a sub-term for bridging social capital (Woolcock 2004). The interviews suggest that small local tourism entrepreneurs in Tornio and Haparanda do not have strong linking social capital with respect to the local managing authorities. Nevertheless, the transmission of new information to the agents that need it is understood to support the emergence of bridging social capital (Callois \& Aubert 2007, p. 812), and in this regard, the Destination project can be seen to have, at least to some extent, increased trust and bridging social capital between the project stakeholders. The perception of trustworthiness has been fostered through information exchange, for example some Finnish entrepreneurs emphasized that the organized meetings and discussions with other entrepreneurs from the region has increased openness and solidarity between them:

You are able to tell about and recommend the other regional (accommodation) options and not try to get all the customers only for yourself. You should give people information about different accommodation options. It doesn't matter where they stay as long as they stay in this region. Of course that kind of (cross-border) cooperation and discussions generates openness, as you get to know the other firms and the people. (TORNIO/PRIVATE/4/FEMALE)

Among the different interest groups there are different opinions concerning what kind of cooperation networks would be most beneficial to regional development. Several entrepreneurs claimed that the towns of Tornio and Haparanda are concentrating (using time and economic resources) overly much on bilateral municipal cooperation and thus excluding options for geographically wider networking, which was considered problematic from the perspective of tourism development as well regional development in general. This underscores the importance of heeding the possible negative effects of using social capital for one group's benefit but also of taking into account the unequal power held in a network (Malecki 2012). Bonding social capital is normally associated with an inward-looking development perspective, yet the experiences of CBC suggest that also bridging social capital can be divisive and in many ways geographically and culturally exclusive.

\section{Norms and values of cooperation}


It is argued that all formulations and applications of the concept of social capital are based on the idea of reciprocity being the key mechanism by which relationships become institutionalized and transformed into collective assets (Staber 2006, p. 193). General reciprocity means simply that a person does something for another "without expecting anything specific back, in the confident expectation that someone else will do something else for him/her down the road" (Putnam 2000, p. 21). The expectation of reciprocity and equality as important norms of cooperation, which influences how affairs should be organized between actors, was strongly present in the interviews. Both private and public sector actors underlined how it is first and foremost important that the organization they represent benefit from the projects they take part in.

In order to practice the norm of reciprocity one needs to trust the other participants. In small businesses in particular a willingness to invest resources in cooperation necessitates institutional and social trust. The former is needed with respect to the institutional vision of the project whereas social trust is necessary for effective interaction among the participants. The norm of general reciprocity is important in terms of project participation, especially because the expected benefits will not come immediately, and from a business's perspective it may even be unclear what the actual benefits of the project are. The interviews suggest that distrust increases when expectations and the norms of reciprocity are not taken into account in the project implementation.

Besides reciprocity, the interviewees emphasized the importance of equality in CBC. National equality is argued to be one of the main norms defining such cooperation, especially when economic benefits are in question (Prokkola 2011, p. 1003). Although the national dimension of equality was highlighted in Tornio and Haparanda, it was not restricted to that. In the case of the Destination project, the (in)equality between big and small enterprises was a significance matter of concern. The project participation fee, which was several hundred euros, provides an example of the problematics of equality. Several small entrepreneurs noted that they were in an unequal position because for them the fee is a relatively larger investment compared to firms with higher net revenues, something that created general mistrust towards the project institution.

An examination of the materials indicates that from the perspective of the norms and values of cooperation, local institutional contexts are of crucial importance. Several interviewees pointed out that local knowledge and existing networks are crucial for the establishment of effective cooperation and project coordination. The participant's familiarity and identification with the project manager may facilitate trust building in the project, that is, the project manager should know 
"how things are done here". It was stated that knowing local people and being familiar with the local habits supports the actor's operations, communication and networking efforts:

(Speaking of recruiting project managers) ...it is forgotten that local persons with existing contacts are a good resource. For a person coming from outside, it takes around one year just to create those contacts and to get to know the regional entrepreneurs and actors. (TORNIO/PRIVATE/5/MALE)

In the context of $\mathrm{CBC}$, the question of language illustrates how local social capital is created and used through social networks that are defined by local experiences and the norms of trust and solidarity (cf. Riipinen 2008). In Tornio and Haparanda there is a common norm of using either Finnish or Swedish as the language of communication. English is not considered a preferable option for communication because for the local people appreciation of the local language culture is of great importance. As one interviewee stated: "English is a common language but it is not a common state of mind" (SWE/FIN/PUBLIC2/MALE). This is explained by the fact that in the Swedish-Finnish border area many people speak Finnish because of migration or their knowledge of Meänkieli, the regional minority language which has its roots in Finnish. Secondly, the Swedish language has an official status in Finland and studying Swedish is included in the Finnish school curriculum. Multilingualism as a norm of cooperation is strong; according to one interviewee, actors in cooperation projects even hesitate to admit that their language skills are not sufficient. This indicates that they may posit themselves in a weaker position when constrained by the local norms and beliefs about language skills expectations:

The basic problem here at the Finnish-Swedish border is that people don't admit if they don't know the neighbor's language properly. Still, they sit in the negotiations and laugh at the right moment and everybody thinks that you understood. [...] When you need to read between the lines, those things will be missed. [...] Then you are an underdog in that negotiation. (TORNIO/PUBLIC/1/MALE)

Furthermore, in Tornio and Haparanda, there is a principle that if a meeting takes place on the Swedish side, the primary communication language is Swedish and vice versa. Interpretation, of course, is always organized if needed. Some of the public sector actors in Tornio argued, however, that Swedish actors benefit from underlining this norm and even have the possibility to gain an 
important asset in negotiations. Native and non-native language speakers are put in an asymmetrical position:

In Sweden some of the people use it as a negotiation asset. It is significantly easier to negotiate with your mother language if the other person uses fair Swedish as the native speaker understands also the nuances. (TORNIO/PUBLIC/2/MALE)

Although the language norm is understood to support equity and trust between the actors on both sides of the border, it can also be used as a tool for exercising power over others, something that emphasizes the role of human agency in the processes of social capital. In this context the power is created by mobilizing an informal institutional resource and thereby achieving a more powerful position in the negotiation situation and decision-making process. Moreover, while committed to cooperation and developing a common 'twin city', city officials are firstly loyal to the aims and objectives of the organization they represent and, presumably, exploit the available resources to secure them.

\section{Conclusions}

The aim of this paper was to study how the processes of social capital and power relations are manifested in the context of CBC in the border towns of Tornio and Haparanda, often presented as forerunners of $\mathrm{CBC}$. We have highlighted the fundamental yet thus far neglected role of power in $\mathrm{CBC}$ and that the effects of social capital processes are not predictable or unproblematic but need to be approached as context dependent. While CBC emerges in certain frames of multi-scalar formal governance (implemented mainly with public sector funding), in order to succeed and continue cooperation at the local and regional levels, the activities need to be built on informal social capital and trust between stakeholders. In addition, power relations within the project networks are often unbalanced and the exercise of power becomes manifested through the mobilization of resources to which some actors or interest groups, such as small enterprises, might not have access.

The processes of how project networks form and how various power relations come into play are essentially important when trying to understand the trajectories of regional development and cooperation. In the selection of project partners and the strategic formation of membership in particular, the use of bridging social capital occurs alongside other forms of capital, that is, the 
material and cultural resources of the partners and their location in the knowledge economy. The realization of new projects and securing of funding requires seeking out and coordinating with partners from other regions and industries. As $\mathrm{CBC}$ projects bring together various interest groups and actors who do not necessarily share the same interests (see also Jacobs \& Kooij 2013), balancing between common and vested interests is therefore a continuously present concern. Unequal power relationships, unevenness and over-embeddedness of national or sectoral social capital can also reduce or limit the benefits of social capital in CBC (cf. Malecki 2012, p. 1042). This paper shows how in Tornio and Haparanda many stakeholders had experienced exclusion and inequality in $\mathrm{CBC}$ projects.

The examination of the cooperation in Tornio and Haparanda points out that the local norms, values and beliefs are strongly intertwined with the processes of social capital and trust building. In the studies on $\mathrm{CBC}$, national divisions are usually seen as the key obstacles of cooperation (Fabro \& Haselsberger 2009). Language differences and practices provide a fitting example here (Mirwaldt 2013) and were also present in Tornio and Haparanda. Language and particularly the local norms concerning the choice of language in meetings indicate that social capital is used in strategic ways in $\mathrm{CBC}$. Thus there is a need to better understand the role of language as a resource for exercising power in different $\mathrm{CBC}$ contexts.

Yet interviews with different actors in the Tornio and Haparanda area suggest that the state border and national division provide only one factor through which to evaluate the success of cooperation initiatives. Unbalanced power relations between different interest groups and their strategic use of social capital can strongly affect the results of the initiatives. Nevertheless, the role of the institutional framework in which the different power relations between interest groups are manifested should not be overlooked. Although it can be argued that the exclusion of certain private sector actors is dependent on the interests and skills of local administrative officials, it is also strongly dependent on the institutional preconditions framed by regional, national and EU authorities. Accordingly, the power relations and the roles of local officials and entrepreneurs are to some extent imbalanced already to start with, and therefore not directly comparable.

It has been argued that social capital has become a matter of concern precisely because of regional politics and political interests, not in spite of them (De Souza Briggs 2004, p.154). In future studies, it is important to pay more attention to the processes of social capital in CBC as well as how they are interlinked with politics and actions that advance particular strategies and interests in border 
towns and regions. One of the key objectives of the Interreg programs is to promote EU territorial coherence, regional competitiveness and networking, as well as to strengthen the feeling of solidarity across national borders. The promotion of these matters, however, is often interwoven with particular political and local interests. In Tornio and Haparanda, the marketing value of CBC encourages the towns to invest in cooperation because it is understood to support their own strategic development objectives; on the other hand, the existing forms of social capital and trust relations influence how this political strategy is manifested. The long history of $\mathrm{CBC}$, and the norms and values related to it, support the building of common regional development strategies and profitable political decisions. The political struggle and vested interests between different interest groups plays an important role in the processes of social capital in $\mathrm{CBC}$ and has an impact on the trajectories of regional development. However, trust relations and vested interests are not a zerosum game but can both exist simultaneously in CBC networks. When studying the success of CBC projects, it is important to give due attention to the question of reciprocity and equality; inclusive and equal coordination, communication and decision making are crucial in regard to mobilization, engaging and trust building between project participants and interest groups.

\section{References}

ALLEN, J. (1997), Economies of power and space. In R, LEE \& J. WILLS Eds. Geographies of economies. pp. 59-70, John Wiley \& Sons, New York.

AMIN, A. (2001), Moving on: institutionalism in economic geography. Environment and Planning A 33, pp. 1237-1241.

AULAKH, P., KOTABE, M. \& A. SAHAY (1996), Trust and performance in cross-border marketing partnerships: a behavioral approach. Journal of International Business Studies 27, pp. 1005-1032.

AUNIOLA, A-M. (2017) Personal telephone discussion conducted on Janury 16, 2017 with Interreg V North program coordinator Anna-Mari Auniola from Regional Council of Lapland.

BOURDIEU, P. (1986). Forms of capital. In Richardson, J.G (eds.) Handbook of theory and research for the sociology of education. pp. 241-260. Greenwood Press, New York.

DE SOUZA BRIGGS, X. (2004), Social Capital: Easy Beauty or Meaningful Resource. Journal of American Planning Association 70, 151-158.

CALLOIS, J-M. \& F. AUBERT (2007), Towards indicators of social capital for regional development issues: the case of French rural areas. Regional Studies 41, pp. 809-821.

CLARKE-HILL, C., LI, H. \& B, DAVIES (2003) The Paradox of Co-Operation and Competition in Strategic Alliances Towards a Multi-Paradigm Approach. Management Research News 26, pp. 1-20. 
CLEMENT, F. \& C. LAMOUR (2011), Social capital design and polycentric metropolitan competitiveness: the "Grande Region" agenda. Journal of Borderland Studies 26, pp. 89-99.

GITTEL, R. \& A, VIDAL (1998), Community Organizing: Building Social Capital as a Development Strategy. Sage Publications, California.

GRIX, J. \& Knowles, Vanda (2003), The Euroregion as a social capital maximizer: the German-Polish Euroregion Pro-Europa Viadrina. Regional and Federal Studies 12, 154-176.

GONZALES-GOMEZ, T. (2014), The social capital applied to cross-border cooperation in the cross-border regions of Alentejo-Algarve-Andalucia and Southerns Finland-Estonia. Doctoral Thesis, University of Huelva, Huelva.

FABRO, S. \& B. HASELSBERGER (2009) Spatial planning harmonisation as a condition for trans-national cooperation: the case of the Alpine-Adriatic Area. European Planning Studies 17, pp. 1335-1356.

ELENIUS, L. (2008), Transnational history and language barriers. Luleå University of Technology.

FERRER-GALLARDO, X. (2009), Territorial (dis)continuity dynamics between Ceuta and Morocco: Conflictual fortification vis-à-vis co-operative interaction at the EU border in Africa. Tijdschrift voor Economische en Sociale Geografic 102, pp. 24-38.

HADJIMICHALIS, C. \& R. HUDSON (2006). Networks, Regional Development and Democratic Control. International Journal of Urban and Regional Research 30, pp. 858-872.

HOLT, L. (2012) Embodied social capital and geographic perspectives: performing the habitus. Progress in Human Geography 32, pp. 227-246.

HOSPERS, G. (2006), Borders, bridges and branding: The transformation of the Oresund region into an imaged space. European Planning Studies 14, pp. 1015-1033.

HÄKLI, J. (2009). Boundaries of trust: building a transnational space in Haparanda-Tornio. Teoksessa Häkli, Jouni \& Minca, Claudio (toim.) Social capital and urban networks of trust. pp. 205-232. Aldershot, Ashgate.

INTERREG VA Nord (2016). Hankekäsikirja. http:// www.interregnord.com/fi/hankekasikirja/. 16.1.2017

INTERREG IVA NORTH (2007), INTERREG IVA Pohjoinen 2007-2013 Ohjelma-asiakirja. http://www.lappi.fi/lapinliitto/c/document_library/get_file?folderId=26286\&name=DLFE-2752.pdf

JACOBS, J. \& KOOIJ, H.J. (2013) Fading euphoria at the Dutch-German border? The case of Avantis. Tijdschrift voor Economische en Sociale Geografic 104, pp. 379-387.

JAKOLA, F. (2013) Sosiaalinen pääoma ja kaksoiskaupunki TornioHaaparannan kehittyminen. Alue ja Ympäristö 42, pp. 63-73.

JAKOLA, F. (2016) Borders, planning and policy transfer: historical transformation of development discourses in the Finnish Torne Valley. European Planning Studies DOI 10.1080/09654313.2016.1194808

KNACK, S. \& P. KEEFER (1997), Does Social Capital Have an Economic Payoff? A Cross-Country Investigation. The Quarterly Journal of Economics 112: 4, pp. 1251-1288. 
LUNDEN, T. \& D. ZALAMANS (2001), Local co-operation, ethnic diversity and state territoriality - The case of Haparanda and Tornio on the Sweden-Finland border. GeoJournal 54, pp. 33-42.

MATSSON BARSK, M. (1993), Tornedalskommunernas Förbund 1941-1991: En historik. In M, RANTAKOKKO eds., Tornionlaakson Vuosikirja 1993, pp. 145-178. Tornionlaakson Kotiseututoimikunta.

MALECKI, E. (2012). Regional Social Capital: Why it Matters. Regional Studies 46:8, pp. 1023-1040.

MEDEIROS, E. (2014), Is there a new trust in inner Scandinavia? Evidence from cross-border planning and governance. Geografiska Annaler Series B-Human Geography 96, pp. 363-386.

MIRWALDT, K. (2013), The Small Projects Fund and Social Capital Formation in the Polish-German Border Region: An Initial Appraisal. Regional Studies 46, pp. 259-272.

MISTZAL, B. (1996), Trust in modern societies. Padstow, Polity Press.

MOHAN, G. \& J. MOHAN (2002), Placing social capital. Progress in Human Geography 26, pp. 191-210. MURPHY, J. (2006), Building trust in economic space. Progress in Human Geography 30, pp. 427-450.

NAUGHTON, L. (2013), Geographical narratives of exercised social capital. PhD Dissertation. Staffordshire University, Stoke-on-Trent.

NAUGHTON, L. (2014).Geographical narratives of social capital: Telling different stories about the socioeconomy with context, space, place, power and agency. Progress in Human Geography 38, pp. 3-21

NORBOTTENS LÄNSTYRELSEN (2012), Slutrapport för perioden 2009-10-01-2012-09-31. Interreg IVA Nord. Länstyrelsen I Norbottens län, Luleå.

NOUSIAINEN, R. (2010), Provincia Bothniensis Haparanda-Tornio - Ainutlaatuinen kaksoiskaupunki. In H, NORDBERG eds., Raja 200 - Gränsen 200, Tornionlaakson vuosikirja 2008-2010.

Tornionlaakson neuvosto, Tornionlaakson maakuntamuseo, Luleå.

O'DOWD, L. (2002) The Changing Significance of European Borders. Regional \& Federal Studies 12, pp.13-36.

PAASI, A. (1996). Territories, boundaries and consciousness: The changing geographies of the FinnishRussian border. John Wiley \& Sons, Chichester, New York, Brisbane, Toronto, Singapore.

PERKMANN, M. (2002) Euroregions: institutional entrepreneurship in the European Union. In M.

PERKMANN, M. \& N. SUM eds., Globalization, Regionalization and Cross-border Regions. pp. 103-124. Palgrave Macmillan, Basingstoke, Hants.

PILECEK, J., CHROMY \& V. JANCAK (2013). Social Capital and Local Socio-economic Development: The case of Czech Peripheries. Tijdschrift voor Economische en Sociale Geografic 4, pp. 604-620.

PRETTY, J. (2003). Social Capital and the Collective Management of Resources. Science 302 pp. 19121914.

PROKKOLA, E-K. (2011) Cross-border regionalization, the INTERREG III A iniatitive, and local cooperation at the Finnish-Swedish border. Environment and Planning A 43, pp. 1190-1208.

PROKKOLA, E-K, ZIMMERBAUER, K. \& F. JAKOLA (2015) Performance of regional identity 
in the implementation of European cross-border initiatives. European Urban and Regional Studies 22, pp. 104-117.

PUTNAM, R. (1993), Making democracy work: civic traditions in modern Italy. Princeton University.

PUTNAM, R (2000). Bowling alone: The collapse and revival of American democracy. Touchstone Books, New York.

RIIPINEN, M. (2008). Sosiaalisen pääoman skaalaus: paikallisia ja ylipaikallisia näkökulmia maankäyttöön Nellimissä, Inarissa. PhD Dissertation, University of Oulu

RODRIGUEZ-POSE, A. (2013). Do Institutions Matter for Regional Development? Regional Studies 47, pp. 1034-1047

ROHE, W. (2004). Building social capital through Community Development. Journal of American Planning Association 70, pp. 158-164

SMALLBONE, D., LABRIANIDIS, L., VENESAAR, U., WELTER, F. \& P. ZASHEV (2007).

Challenges and prospects of cross border cooperation in the context of EU enlargement.

21.4.2016.http://www.bamde.org/germany/Publications/Integrated_lit_review.pdf.

STABER, U. (2006), Social Capital Processes in Cross Cultural Management. International of Cross Cultural management 6, pp. 189-203.

SVENSSON, S. (2015), The Bordered World of Cross-border Cooperation: The Determinants of Local Government Contact Networks within Euroregions. Regional \& Federal Studies 25, pp. 277-295.

TRIPPL, M. (2008). Developing Cross-border Regional Innovation Systems: Key Factors and Challenges. Tijdschrift voor Economische en Sociale Geografic 101, pp. 150-160.

TURA, T. \& V. HARMAAKORPI (2005). Social capital in building regional innovative capability. Regional Studies 39, pp. 1111-1125

VAN DEN BROEK, J., RUTTEN. R. \& P. BENNEWORTH (2015) Innovation and SMEs in Interreg policy: Too early to move beyond bike lanes? http://www.regionalstudies.org/uploads/RSA2015_final_paper_ Jos_van_den_Broek_Roel_Rutten_Paul_Benneworth.pdf. 16.1.2017

WOOLCOCK, M. (2004), Why and How Planners Should Take Social Capital Seriously. Journal of American Planning Association 70, pp. 183-189. 
Figure 1. Map of the town center areas of Tornio and Haparanda 